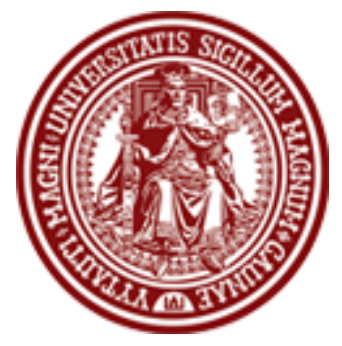

BALTIC JOURNAL OF LAW \& POLITICS

VOLUME 2, NUMBER 2 (2009)

ISSN 2029-0405

http://www.versita.com/science/law/bjlp

Cit.: Baltic Journal of Law \& Politics 2:2 (2009): 74-102

DOI: $10.2478 / \mathrm{v} 10076-009-0012-\mathrm{x}$

\title{
INSTITUTIONAL CONTEXTS OF THE IMPLEMENTATION OF QUALITY INITIATIVES IN THE PUBLIC SECTORS OF FINLAND \\ AND LITHUANIA
}

\author{
Remigijus Civinskas \\ Associate Professor; Dr. \\ Vytautas Magnus University Faculty of Political science and Diplomacy \\ (Lithuania) \\ Contact information \\ Address: S. Daukanto str. 28, LT-44246 Kaunas, Lithuania \\ Phone: (+370 37) 327871 \\ E-mail address: r.civinskas@pmdf.vdu.It

\section{Mindaugas Kaselis}

\section{Doctoral Candidate} \\ Vytautas Magnus University Faculty of Political science and Diplomacy \\ (Lithuania)

\section{Contact information} \\ Address: S. Daukanto str. 28, LT-44246 Kaunas, Lithuania \\ Phone: (+370 37) 327871 \\ E-mail address: m.kaselis@pmdf.vdu.It
}

Received: December 02, 2009; reviews: 2; accepted: January 07, 2010.

\section{ABSTRACT}

This article reports the results of research of public service quality reform initiatives in Lithuania and Finland. Research reveals that quality management has been in vogue within the manufacturing sectors of both countries for several decades. The service industries have made heavy investments in this area. There are also major initiatives from the public sector to improve quality. This paper examines and compares the development of reform conceptions and programmes in terms of institutional interest and power positions. It demonstrates that the initiation and progress of reform initiatives were determined by 
particular unforeseen and accidental circumstances in both countries. On the other hand, it explains why Finnish institutions were ready for a constructive dialogue, and a pilot try-outs option in implementation or reform instruments. Lithuanian institutions, by comparison, are characterized by the creation of new structures and self-seeking interests. Finally, the paper reveals how the instruments of public service quality improvement were implemented in both countries.

\section{KEYWORDS}

Public Quality Management, Public Service Reform, Institutionalism, Change in Public Organizations 


\section{INTRODUCTION}

Modernization of public administration and realization of the satisfaction of the needs of citizens as customers of public sector services can be expressed through the prism of quality management. Therefore, initiatives of quality management may have influence on real changes in the public sector which are important not only for the achievement of a more effective functioning of public organisations, but also for the raising of trust in civil service in principle. Nevertheless, instruments of quality management can also be employed solely for the appearance of changes in public sector processes which will include wasting of both material and human resources. Thus, it is worth exploring whether appropriate conditions are being created for the development of quality management initiatives on the plane of public administration. In order to best analyze the problems of the application of quality management in the Lithuanian public sector, the Republic of Finland has been chosen for comparison, because it is the country that public administration theoreticians label as a leader in the application of reform models in Europe.

Therefore, the aim of this work is to explore the problems of the employment of quality management initiatives in the sectors of public administration of Lithuania and Finland.

In order to achieve the aim of the work, the following tasks have been set:

1. To investigate reasons and incentives for the application of quality initiatives in the public sectors of Finland and Lithuania;

2. To examine the interests of actors from the aspect of the application of quality initiatives in Finland and Lithuania.

\section{Description of research methods}

In order to accomplish the proposed tasks, the method of qualitative data analysis, and semi-structured interview, has been used. This research method has been chosen for the purpose of achieving greater consistency in addressing the problems at hand.

Specific research questions have been formulated to specify and deepen each of the more general questions. In asking the questions provided below, attempts have been made to explore not only expressions of quality initiatives, but also reasons for decisions and the contexts of that decision-making.

Essential criteria for the selection of experts involved work practices in applying or analysing/assessing quality systems. It was decided that a semistructured interview had to be conducted with Finnish and Lithuanian politicians of 
central and local government institutions, civil servants, experts and specialists. The research also involved officers of institutions under central or local government and representatives of universities and private companies whose direct work is related to quality management. In total, 6 Finnish and 8 Lithuanian experts took part in the qualitative research. ${ }^{1}$

\section{Time and place of the research}

The qualitative research was carried out in 2008 and the beginning of 2009 in the Republics of Lithuania and Finland. In the latter country, the semi-structured interview was conducted in two cities: Helsinki and Vaasa; in Lithuania, the analysis of qualitative research involved interlocutors from the two biggest cities of Lithuania: Vilnius ${ }^{2}$ and Kaunas.

\section{Introduction of the Conceptual Method}

The tasks of the analysis of qualitative research data and the problems chosen are complex enough; therefore, conceptual tools have been employed. In establishing the conceptual foundations of the analysed research, certain problems can be highlighted most consistently by the use of a model which links categories of two different theoretical perspectives. On the one hand, the research analysis has employed aspects of C. Pollitt and G. Bouckaert's model of Public Management Reform which reflect factors influencing the spread of innovations in the public sector. On the other hand, deeper research analysis, which addresses the problems of creation and application of quality initiatives, used categories of sociological and new institutionalism, which were combined with the conceptualized context of the model of Public Management Reform.

It should be noted that these two conceptions employed in the work are partly contradictory, but they are linked by common premise of examining not only factors influenced by environment, but also deep incentives of reform strategies for

\footnotetext{
${ }^{1}$ In order to carry out a qualitative semi-structured research interviews with the following respondents from Finnish institutions have been employed: Finland, Vaasa Municipality, Administration Director Veli Matti Laitinen; Finland, Ministry of Finance, Public Management Department, Management and Public Services Division, Counsellors Katju Holkeri and Johhanna Nurmi; Finland, Local and Regional Authorities Association, Head of Development Salme Sunquist; Finland, Institute of Public Management, Head of Training Lauri Luoto; Finland, "Excellence Finland" Quality Award Projects Director Timo Tulonen.

During the qualitative research in Lithuania interviews with the following respondents have been used: Lithuanian Institute of Public Administration, Chief Consultant Artūras Arbatauskas; Kaunas City Municipality, Head of Administration Office Valentinas Markevičius; Member of the Seimas (Parliament) of the Republic of Lithuania, Andrius Kubilius; Member of the Seimas (Parliament) of the Republic of Lithuania, Gintaras Steponavičius; Public Policy and Management Institute, Analyst Ramunè Cerniūtė; President of Lithuanian Quality Management Association, Kaunas University of Technology, Head of Quality Management Department Povilas Vanagas; "Uolektis, Ltd." Director Alma Žemaitienè; "Uolektis, Ltd." Manager - Consultant Evelina Petrauskaitè.

2 The choice of institutions in the capitals of both countries was determined by the factor that both in Vilnius and Helsinki there is an institutional network that forms or in other ways influences the spread of quality management in national administrative fields.
} 
the inspiration and development of quality management initiatives in the Republics of Lithuania and Finland. Thus, the combination of these different theoretical perspectives enables a comprehensive examination of factors influencing the spread of quality management.

Moving on to the presentation of the categories of institutionalism chosen for the analysis of the research, we begin with the concept of the administrative field. Looking from the perspective of institutionalism, as Paul J. DiMaggio and Walter W. Powell explain, once disparate organizations in same line of business are structured into a actual field (as we argue, by competition, the state, or the professions) powerful forces emerge that lead them to become more similar to another. ${ }^{3}$

Such an atmosphere of institution contention is reflected in the so-called administrative or organisational field. The organisational field itself is the totality of organisations (institutions) that interact in a system of common functioning and which contest affecting one another more frequently and more fatally than actors who are outside the boundaries of the field. Building on DiMaggio and Powell's observations, W. Richard Scott maintains that "the organisational field reflects organisations within it which constitute the common recognized arena of 'institutional existence': they involve main suppliers, agencies carrying out the regulation and other organisations providing similar products or services". ${ }^{4}$ Consequently, the administrative field embodies a specific environment of the spread of quality initiatives which has institutional boundaries and where interacting institutions create influence on the configuration of quality management instruments on the plane of public administration.

Another concept employed in this work through the prism of institutionalism is the interest, as each institution has not only powers, but certain interests typical of each institution individually. Although, according to J. G. March and J. P. Olsen, the subjective conception of an institution's interests has to coincide with proper interests, i.e. the ones objectively serving the public, whereas unreasonable priorities and interests should be identified and ignored. ${ }^{5}$ However, the priorities of actors who are rationally interacting in the administrative field have the tendency, more or less, to be self-seeking interests. ${ }^{6}$ In their own turn, the individual preferences of institutions are not stable, as institutions are constantly motivated to form their choices according to the "pleasure-based benefit" and financially

\footnotetext{
3 Paul J. DiMaggio and Walter W. Powell, "The iron cage revisited institutional isomorphism and collective rationality in organizational fields": 65; in: Walter W. Powell and Paul J. DiMaggio, eds., The New Institutionalism in Organizational Analysis (Chicago: University of Chicago Press, 1991).

${ }^{4}$ Richard W. Scott, Institutions and Organizations (London, New Delhi: Sage publication, 1995), p. 56.

5 James G. March and Johan P. Olsen, supra note 3, p. 155.

6 Jan-Erik Lane and Svante Ersson, The New Institutional Politics. Performance and Outcomes (London, New York: Routledge, 2000), p. 3.
} 
beneficial logic. ${ }^{7}$ Therefore, institutions as rational actors wishing to not only survive, but to prosper in the administrative field will seek to apply strategies practical to them and which also help to realize the individual interests of each institution.

Nevertheless, each institution has different possibilities for realizing its interests if each of them has the disposition of unequal powers that are delegated to them by the legislation and which form relationships among actors of the administrative field. Probably the most significant expressions of institutional power involve the legitimacy of institutions, funds (financial power) and autonomy. Legitimacy is related to the formal and constitutional (legal) power of institutions to operate in the way it is authorised to them legally. To institutions, funds (financial resources) constitute a very important leverage not only when seeking the realization of their own goals and interests, but also when "trying to survive, prosper and grow". ${ }^{8}$ Autonomy or, in other words, freedom of institutional action, also gives them powers with the help of which institutions are able to realize certain objectives and form preferences and priorities.

Moreover, institutional powers are linked to an individual limit of action of each institution that implies a particular space where it is legally determined for an institution to operate and perform their functions. In other words, this is the division of responsibility among institutions, each of which has a collection of different rules. ${ }^{9}$ Thus, every institution as a rational actor operating within its individual limits of action of the administrative field and having the disposition of certain powers will seek to realize and self-seeking interests of its institution.

The implementation of such self-seeking interests is also ensured by institutions through inter-institutional deals (with other actors of the administrative field) successfully concluded and favourable to them. In their turn, interinstitutional deals themselves determine a necessary means when aiming at the spread of processes of effective external changes. ${ }^{10}$ Nonetheless, J. E. Lane doubts whether concluded institutional deals reinforce the possibility that the public sector will find and implement the best solutions, as the rising of difficulties of public administration and public management is influenced by uncertainty and opportunism lying in relationships of actors of the administrative field. ${ }^{11}$ Therefore, institutions as rational players aiming at quality initiatives of changes emerging

\footnotetext{
${ }^{7}$ Richard W. Scott, supra note 4, p. $27-37$.

8 B. Guy Peters, Biurokratijos politika (The Politics of Bureaucracy) (Vilnius: Pradai, 2002), p. 298.

9 James G. March and Johan P. Olsen, Rediscovering Institutions. The organizational basis of politics (New York: Free press, 1989), p. 27.

10 James G. March and Johan P. Olsen, Institutional Perspectives on Governance (Bergen: Norwegian research centre in organization and management, 1993), p. 12.

${ }_{11}$ Jan-Erik Lane, Viešasis sektorius: sąvokos, modeliai ir požiūriai (The Public Sector: Concepts, Models and Approches) (Vilnius: Margi raštai, 2001), p. 376.
} 
under the scenarios beneficial to institutions themselves in the administrative field will use inter-institutional deals for the realization of their own (self-seeking) interests or reinforcement of their own positions in the administrative field.

It is evident that the development of deals advantageous to institutions of the administrative field is closely related to the disposition of certain information among institutions. Therefore, in the administrative system with a competitive shade, information is an instrument of strategic actors. ${ }^{12}$ Institutions cannot avoid problems related to information, since knowledge which can turn out to be of service to the fulfilment of interests of some actors is not neutral or objective. ${ }^{13}$ Thus, information may be correct or false, but, in any case, it always serves a particular purpose. Although actors may provide accurate information about their choices, they would not usually behave in this way unless they acted tactically. Hence information itself is a game or a ploy and it tends to be self-seeking, except in those cases when and in so far as the structure of the ploy allows honesty which is a necessary tactic. ${ }^{14}$ In other words, information constitutes a significant trump card which tends to be used by institutions in their interrelationships under certain considerations favourable to them.

However, building on the Christopher Pollitt and Geert Bouckaert's model of Public Management Reform, it is possible to maintain that possibilities of changes in the public sector are determined by, and the interest in the administrative change itself arises from, the most different actors whose duties are not directly related to the spread of quality management initiatives: incentives or initiatives of the administrative elite, representatives of the political layer and external experts. ${ }^{15}$ These actors can be impelled to initiate quality initiatives by different subjective or objective circumstances or interests. In certain cases, because of personal and subjective elitist incentives of authorities only the manipulation of changes can be evidenced. Meanwhile objective causes of change such as, for instance, socialeconomic crises sweeping countries may heavily influence and affect real changes of administration. In addition, C. Pollitt and G. Bouckaert in their model of Public Management Reform noted that the pressure upon citizens or decline of the citizens' trust in the public government can also act as an impulse for the formation of modern initiatives.

Finally, the formation of administrative changes can be also influenced by unforeseen and accidental events, factors and circumstances the importance of which may turn out to be decisive for the "birth" of particular quality initiatives.

\footnotetext{
12 James G. March and Johan P. Olsen, supra note 9, p. 10.

13 James G. March and Johan P. Olsen, Democratic Governance (New York: The Free Press, 1995), 81.

14 James G. March and Johan P. Olsen, supra note 9, p. 10.

15 Christopher Pollitt and Geert Bouckaert, Viešojo valdymo reforma: lyginamoji analizè (Public Management Reform: A Compararative Analysis) (Vilnius: Algarvė, 2003), p. 43.
} 


\section{THE CONTEXT OF INTERESTS IN CHANGES OF THE PUBLIC SECTOR}

The summation of qualitative research data has shown that ideas of NPM reached Finland as far back as 1987 and in the layers of government the opinion was formed that citizens as taxpayers should also be treated as customers who must not have bureaucratic obstacles thrown in their way, but must be served to orienting to the quality of results and services. ${ }^{16}$ However, according to the Head of Development of the Finnish Association of Local and Regional Authorities Salme Sundquist, at that period it was difficult to persuade not only citizens, but also the municipalities themselves that quality systems can tangibly solve problems, since both among officers of the municipality and among citizens an unfounded opinion prevailed that the means of quality were expensive. According to this officer, the determination that it is necessary to undertake more decisive projects in order to change the established opinion in Finland came under completely unexpected circumstances: "In the beginning of the last decade at the London Heathrow Airport while waiting for the plane a conversation got started with a fellow-traveller, a famous member of a private company, with whom discussing perspectives of future organisations I heard the opinion that quality challenges in public organisations like in private ones should be also important and that their importance would increasingly grow in the future". This dialogue significantly contributed to S. Sundquist's additionally increased enthusiasm to concentrate her work activity almost exclusively upon the area of quality in public administration. ${ }^{17}$ Soon she started intensively collaborating with private organisations in Finland (especially industrial ones) that were implementing quality systems and after becoming comprehensively acquainted with which she wrote the article "What Quality Management Means in Municipalities of Finland". This publication received response from government officials and especially made an impact on and prompted the then civil servant at the Department of Public Management of the Ministry of Finance of Finland Hilkka Summa-Pollitt ${ }^{18}$ to contact the author of the mentioned article and to muster up the united institutional strength in the name of the popularization of quality models in public sector organizations of Finland. It is interesting that $\mathrm{H}$. Summa-Pollitt, while working in the Ministry of Finance of Finland, encouraged S. Sundquist to apply to the Ministry of Trade and Industry of Finland for the assurance of the sponsorship in organizing an experimental (pilot) ISO 9000 project

\footnotetext{
${ }^{16}$ Katju Holkeri, personal interview, April 7, 2008.

17 Salme Sundquist, personal interview, April 8, 2008.

18 Hilkka Summa-Pollitt presently holds the position of the Head in one of divisions of the European Commission's Directorate-General for Agriculture and Rural Development and she is a wife of a famous public administration researcher Christopher Pollitt.
} 
in 1993 in which, according to established criteria ${ }^{19}, 5$ Finnish public organizations were selected to participate. It should be noted that all Finnish municipalities (there are 452 of them) had the option to enter the pilot project (proposals had been sent to all of them); therefore, a sufficiently numerous team of them, a bit less than a half (200), expressed interest in the ISO series of standards. ${ }^{20}$ The purpose of this experimental project was to determine the applicability of the ISO series of standards in improving the quality of municipal services ${ }^{21}$ and to prove to the municipalities that quality systems are not high-cost for organizations and that a positive attitude towards quality determines the efficiency and productivity of public services. $^{22}$ Thus, it is evident that accidental circumstances (the unplanned conversation at the airport) in Finland was that factor which contributed to the situation that during an especially short period of time a great involvement in quality initiatives occurred in public organizations. In addition, findings of the carried qualitative research show that ideas or visions generated by officials of the country and publicly declared instantaneously receive the support from other officials of government institutions (it would be difficult to agree that the same practice has also spread in Lithuania) when realizing quality initiatives in practical activity. In its turn, the mode of the applicability of the ISO standards in Finnish municipalities symbolizes that quality models are not initiated on a broad scale, but in order to assess possibilities of the application of quality initiatives in the country's public sector they are introduced in a pilot way.

Meanwhile, in Lithuania, where the practice of the application of quality initiatives exclusively in public organisations of a broader scope started almost a decade later than in Finland, it is also possible to spot accidental circumstances in the context of initiation. For example, the Chief Consultant of the Lithuanian Institute of Public Administration Artūras Arbatauskas, in 2003, as he himself admitted, "accidentally" found in the Internet the 2000 version of CAF (Common Assessment Framework, hereinafter CAF) which especially fascinated him: "This is an engaging framework, as the results of self-assessment depend not only on workers, but also on the work of leadership and constituent parts such as processes, strategy and partnership". Thereby, already the following year (2004)

19 Public organizations wishing to participate in the pilot project of the implementation of ISO 9000 standards had to fulfil the following requirements: they had to be from different parts of Finland (the truth is that this criterion was not fully fulfilled, as public organizations of Espoo and Vantaa were selected, the cities that appear in the Helsinki region) and representatives of different sectors; within the organization they had to have a representative who was responsible for the spread of quality; and organizations had to be selected from both large and small municipalities according to the size of population.

20 Salme Sundquist, supra note 17.

${ }^{21}$ Salme Sundquist, "Finnish Local authorities experiences with use of ISO 9000": 117; in: Elker Loffler and Mirko Vintar, eds., Improving the Quality of East and West European Public Services (Hampshire: Ashgate, 2004).

22 Salme Sundquist, supra note 17. 
this specialist with great interest went to the third international conference on quality in Rotterdam where it was possible to get a lot of both theoretical and practical information on the CAF model, as the best cases of countries in the application of this quality initiative were presented. According to A. Arbatauskas, although the conference saw a great flow of people, he nevertheless succeeded in meeting by chance representatives of the Ministry of the Interior of Lithuania who were also interested in the CAF. This "acquaintance" helped create a close partnership between the Lithuanian Institute of Public Administration and the Ministry of the Interior of Lithuania in the implementation of the CAF in the system of Lithuanian public administration, since, according to A. Arbatauskas: "That meeting in Rotterdam impelled us to collaborate initiating the 2005 issue of the CAF that we jointly translated into Lithuanian, adjusted the conditions of and polished". ${ }^{23}$ Therefore, building on the material of the qualitative research, it is possible to maintain that ideas of quality management initiatives by representatives of Lithuanian institutions are generated on an informal plane of inter-institutional collaboration. On the other hand, the analysed case testifies that the CAF has been adopted as an example of the best practice in the international space which, thanks to inter-institutional deals, is literally transferred into the practice of Lithuanian public administration as a non-organic model. In its turn, such a hasty method of the "copy-paste" application without any preceding studies of possibilities ${ }^{24}$ or other investigations into the validity of the initiative for the functioning in the system of Lithuanian public administration brings the idea that behind the protection of such a sudden quality model someone's personal interests may be lurking as well.

Thus, in the practice of both Lithuania and Finland, the context of accidental circumstances and that of the generation of ideas "have contributed" to the spread of quality initiatives. However, as findings of the qualitative research determine, the initiation of quality management models in Finland involved the implementation of the ISO standards in an organized way with the experimental project being employed; whereas in Lithuania, the CAF was adopted in the so-called manner of copying.

Turning to the interest of administrative elite in innovations of quality management, it can be noticed that their backing and support is especially to the purpose of anchoring new initiatives in countries. For example, both the earlier mentioned A. Arbatauskas and the Head of the Office of the Administration of Kaunas City Municipality Valentinas Markevičius ${ }^{25}$ maintain with certainty that three

\footnotetext{
${ }^{23}$ Artūras Arbatauskas, personal interview, April 18, 2009.

${ }^{24}$ Besides, in Lithuania, by the order of the Ministry of the Interior the possibility study on the Citizens Charter has been carried out.

${ }^{25}$ Valentinas Markevičius, personal interview, April 21, 2008.
} 
to four years ago Lithuania had a "great" advocate and supporter of the CAF model among the administrative elite. The then Deputy Director of the Public Administration Department at the Ministry of the Interior Jurgita Domeikiené ${ }^{26}$, according to A. Arbatauskas, was "that engine that did not allow to be asleep and actively propelled matters of quality initiatives in the context of Lithuanian public administration". ${ }^{27}$ Through the efforts of this public official the CAF model was being energetically represented in Lithuanian quality conferences and public organisations were actively urged to enter processes of a new quality initiative. Therefore, it can be stated that, although quality initiatives such as the CAF are being literally "transferred" into the system of Lithuanian public administration, nevertheless, in order that they would spread more rapidly among public organisations the backing of senior civil servants and active support of their dissemination and even promotion is necessary. For instance, analyzing the data of the qualitative research, the roles of quality enthusiasts - leaders among administration representatives are apparently manifest and their shifts lead to the deceleration in the application of initiatives.

Nonetheless, in Finland, on the basis of the already mentioned case of the ISO 9000 pilot project, it can be noticed that the initiation of quality models has also received support from officials of the administrative apparatus. Generally speaking, the respondents chosen for the qualitative research in Finland were inclined to maintain that in the country the attitude of civil servants towards administrative reforms was especially constructive not only when aiming at changes, but also in terms of the fulfilment of that through a close collaboration. This is proven by the forum "Administration club" (fin. Hallintoklubi) that exists in the space of Finnish public administration and where public officials meet to discuss questions of administrative reforms.

Meanwhile a potential application of the CAF model in the system of the Finnish public sector was also supported by administration representatives who, in their work activity, were generating new management ideas in the public sector. As it emerged during the qualitative research, the Counsellors at the Public Management Department of the Finnish Ministry of Finance, Katju Holkeri ${ }^{28}$ and Johanna Nurmi, as far back as 1999 were included into the group of Innovations in the provision of public services where the CAF model and was developed on the scale of the EU. In addition, according to K. Holkeri, Finland's Presidency of the

\footnotetext{
26 Presently holding the position of the Head of the Office of the Government of the Republic of Lithuania.

${ }^{27}$ Artūras Arbatauskas, supra note 23.

28 Besides, Katju Holkeri is a daughter of the former Prime Minister of Finland, Harri Holkeri. The government of this politician during its governance $(1987$ - 1991) in the country from 1987 started receiving first realistic initiatives for the reformation of the public sector.
} 
European Union (in autumn of 1999) coincided with the period when the CAF was being especially actively created, so officers of the country's administration were being notably involved into the process of the CAF formation. ${ }^{29}$ Therefore, it is possible to maintain that, both in Finland and Lithuania, visions for quality systems of some representatives of the administrative apparatus contributed to a more rapid rise of them in the national public administration systems of the countries. Moreover, the qualitative research carried out has revealed that, in Lithuania, among senior bureaucrats one obvious leader appeared who was an active supporter of the CAF simply by herself. Whereas, in Finland, the bureaucratic apparatus was impelled to get involved into not only the creation of a new EU quality initiative, but also the support of it by an objective circumstance, Finland's Presidency of the whole EU during a decisive period of quality initiatives when fundamental preparatory work for the CAF model was being carried out.

Moving on to the analysis of the influence of the political layer on innovative changes, not only the qualitative research data obtained by the authors of the article, but also the facts recorded in publications published by the order of the Finnish Ministry of Finance make it possible to state ${ }^{30}$ that in Finland during the last two decades all public management reforms in common have received great political support from governments. As Professor at the Faculty of Public Administration at the University of Vaasa in Finland Ari Salminen puts it, already since the very end of the $9^{\text {th }}$ decade of the last century the development of changes in the public sector in Finland has seen the formation of a "friendly-favourable" environment and the changing of Prime Minister from Harri Holkeri to Paavo Lipponen have been forming notably similar policies of administration reforms ${ }^{31}$ that allowed the ensuring of consistency and success of the spread of innovative means. In truth, although reforms of public administration themselves have been rarely used as a trump card during election campaigns and have not constituted a frequent topic for public debates, they nevertheless have quite often appeared on lists of political agendas. In particular it would be worth emphasizing programmes of central governments which have been of great importance in the context of administration reforms, as each government programme includes a separate clause on management modernization. ${ }^{32}$ Since Finland displays the functioning of a multiparty system, this means that nearly each government is made of coalitions of

\footnotetext{
${ }^{29}$ Katju Holkeri, supra note 16.

30 For instance, see Juhari Turunen, Jorma Kajalainen and Teuvo Metsapelto, Finnish Public Management: Building Sustainable Quality (Helsinki: Ministry of Finance, Edita Prima Ltd, 2006); Christopher Pollitt, Trajectories and Options as International Perspective on the Implementation of Finnish Public Management Reforms (Helsinki: Ministry of Finance, Public management department, 1997).

${ }^{31}$ Ari Salminen, "The Reform "Industry" in Finnish Government": 144; in: B. Guy Peters and John Pierre, eds., Politicians, Bureaucrats and Administrative Reform (London, New York: Routledge, 2001).

32 Juhari Turunen, Jorma Kajalainen, and Teuvo Metsapelto, supra note 30.
} 
separate parties ${ }^{33}$ that generally have unanimously supported changes of public administration and the development of innovations. ${ }^{34}$ Such a united vision towards innovative processes on the political level has been developed since 1987 in the socalled Committee of Ministers on Public Management Reform, formed on a regular basis (also called the Working Group of Ministers on Public Management Reform). Thus, in Finnish coalition governments members delegated by each party to such a Working Group of Ministers have had the possibility to express the position of their fellow party members on innovatory public sector initiatives constructively seeking for a common denominator, which determined that a strong backing from the political level helped public sector initiatives to quickly achieve goals of the public sector modernization. ${ }^{35}$

However, although coalition governments also dominate in Lithuania, nonetheless, the programme attention of governing parties towards the modernization of the public sector management and quality initiatives has been differentiated. At this point, it is possible to distinguish the Homeland Union Party (Lithuanian conservatives) in the programme of which one can discern the ideas and visions of changes of the Lithuanian public sector of not a conservative deviation, but on the contrary, advanced and innovatory ones. For example, in the 2003 programme of this party entitled "The Right Alternative: Success Lithuania" Lithuanian conservatives state that "a strong state is the state that is managed not bureaucratically, but according to the principles of NPM in which the most important thing is the care of the citizen who and is offered services provided by the state". Furthermore, representatives of the Homeland Union also emphasize the benefit of the application of NPM principles due to the fact that their realization not only enables to more efficiently provide public services focusing on citizens and eliminates bureaucratic management, but because at the same time it reduces conditions for the spread of corruption. ${ }^{36}$ Meanwhile the Lithuanian Social Democratic Party (LSDP) staying in the government coalitions of the Republic of Lithuania from 2000 to 2008 in their programme provisions do not tend to advanced ideas of the public sector management and quality initiatives to such a wide extent as their constant rivals conservatives.

Therefore, an analysis of the programmes of the chosen systemic Lithuanian parties reveals that the LSDP, as a permanent political organization that since 2000 in the government of the Republic of Lithuania has had representatives of the

33 Markku Temmes, "Finland and New Public Management," International Review of Administrative Sciences Vol. 64 (1998): 444.

${ }^{34}$ Christopher Pollitt, supra note 30, p. 37.

35 Juhari Turunen, Jorma Kajalainen and Teuvo Metsapelto, supra note 30.

${ }^{36}$ Andrius Kubilius et al, Dešinioji alternatyva: Sékmès Lietuva. Konservatyvioji politine programa (The Right Alternative: Success Lithuania. Conservative political programme) (Vilnius, 2003), p. 15-16. 
highest political level, has showed a casual consideration for quality initiatives in the public sector. Whereas nearly constantly since 2000, government opposition parties (the Homeland Union and Liberals' Movement of the Republic of Lithuania), as the analysis of their programmes and qualitative research shows, at least in the programme, seek to orientate themselves towards quality management on the plane of public administration. The endeavour of the Liberals' Movement directed towards the improvement of quality in the public sector is probably related to the willingness to justify the ideology of liberalism. In the Homeland Union, the application of NPM ideas in Lithuania has been generated by the personal interest of separate authoritative personalities in innovative initiatives in the public sector. For instance, during the qualitative research the party's leader Andrius Kubilius stressed: "I was interested in the quality initiatives of Canada and Great Britain that tangibly improved administration processes, thus there is something we can learn from and apply in the Lithuanian public sector". ${ }^{37}$ However, probably the principal initiator of NPM ideas in the Conservatives' Party is the member of Vilnius City Council Board, Member of Parliament, Professor Kęstutis Masiulis, who has accumulated vast experience in innovative processes and initiatives in the public sector, being an especially active personality. The fact that $\mathrm{K}$. Masiulis has a considerable influence on the programme provisions of the Conservatives is also testified by the mentioning of him among the three main authors who prepared the already cited election programme of the Conservatives' Party "The Right Alternative: Success Lithuania".

Finally, moving to the level of the influence of external experts on innovative initiatives in the public sectors of the countries analysed here, on the basis of the qualitative research findings, it may be stated that in Finland proposals by OECD experts have received wide support from politicians and have been sufficiently enthusiastic and realizable. The interviewed respondents of the Finish public administration also remembered the 1999 - 2000 visits to Finland of the most famous world contemporary experts of the academic layer such as B. Guy Peters or G. Bouckaert who had given the central government suggestions on what changes were necessary for the development of the country's public sector in order that the citizens' trust in the public government would not decrease. ${ }^{38}$ So the conclusion can be drawn that, in Finland, great attention is paid by the highest government layer to how to prepare in the most efficient possible way and develop innovatory instruments of the public sector. This means that not only the most eminent

\footnotetext{
${ }^{37}$ Andrius Kubilius, personal interview, April 23, 2008.

38 Johanna Nurmi, personal interview, April 7, 2008.
} 
globally external experts are invited to carry out studies, but that their suggestions are most frequently usefully realized in the practice of the Finnish public sector.

However, in Lithuania, as the exploration of the penetration of potential innovations into the system of Lithuanian public administration has shown, there is an evident lack of a permanent role of external experts. Nevertheless, A. Kubilius points out consultations by Canadian experts during the implementation of the reform of strategic planning in the system of Lithuanian public administration. ${ }^{39}$ After the implementation of this reform, Canadian and Lithuanian public administration experts who had once again conducted an assessment of the reform indicated that Lithuania's efforts to implement strategic planning were recognized on an international level and considered to be a good example to other countries. ${ }^{40}$ Therefore, on the grounds of this case, it is possible to note that, considering other innovatory public administration reforms and applying new quality initiatives, it would be to the purpose also to invite competent foreign experts asking for their consultations or contribution to research. However, building on the contemporary practice of the application of innovations in Lithuanian public administration, it has to be stated that the influence of foreign experts has been very fragmentary.

To sum up this section, both in Lithuanian and Finnish practice, the spread of quality initiatives "has been promoted" by certain unforeseen and accidental circumstances. However, when initiating the models of quality management, as findings of the qualitative research determine, in Finland, during the implementation of the ISO standards in an organized way the experimental (pilot) project was employed; whereas, in Lithuania, the CAF was adopted in the so-called manner of copying. Also, both in Finland and Lithuania, visions for quality systems of some representatives of the administrative apparatus contributed to a more rapid rise of them in the national public administration systems of the countries. Furthermore, the qualitative research carried out has revealed that, in Lithuania, among senior bureaucrats one obvious leader appeared who was an active supporter of the CAF simply by itself. Whereas, in Finland, the bureaucratic apparatus was impelled to get involved into not only the creation of a new EU quality initiative, but also the support of it by an objective circumstance, Finland's Presidency of the whole EU during a decisive period of quality initiatives when fundamental work for the CAF model was being carried out. Analysing the contribution of the political elite to innovatory ideas in the public sector, it can be noticed that Finland displays not just a unanimous attitude towards changes, but its

\footnotetext{
${ }^{39}$ Andrius Kubilius, supra note 37.

40 Nijolè Kundrotienè and Kęstutis Rekerta, "Strateginio planavimo diegimas Lietuvos viešojo administravimo institucijose (Implementation of Strategic Planning System in Lithuanian Public administration)," Viešoji politika ir administravimas No. 3 (2002): 62.
} 
rotating governments also ensure the succession of innovative visions. Meanwhile Lithuanian governing parties do not have clear visions for innovative initiatives of the public sector and opposition parties generating NPM ideas have not gained access to the central government for already eight consecutive years. Finally, the influence of Lithuania's foreign experts on the ideas of the public sector modernization was only fragmentary, while in Finland notably greater attention is paid by the highest government layer as to how to prepare in the most efficient possible way and develop innovatory instruments of the public sector. This means that not only the most famous globally external experts are invited to carry out studies, but that their suggestions are most frequently usefully realized in the practice of the Finnish public sector.

\section{INTERESTS OF ACTORS IN THE FINNISH AND LITHUANIAN ADMINISTRATION FIELDS OF THE APPLICATION OF QUALITY INITIATIVES}

Proceeding with the analysis of actors' interests in the Finnish administrative field of the application of quality initiatives, it should be recalled that actors of the field under legally delegated rights in their interrelationships appear to be very independent each from the other. Besides, the application of quality initiatives in Finland has never been of an obligatory character. Speaking about the most distinct actors of the administrative field who form the quality policy it would be difficult to distinguish one institution. In this northern country, in the context of the quality policy, rather the diarchy predominates. In other words, when forming the quality policy the greatest influence is exerted by the Ministry of Finance and the Association of Local and Regional Authorities.

Although, at first glance it would seem that the powers of these institutions should be unequal, for the Ministry of Finance as a central government institution naturally it would have to "order the music" in the quality policy. However, historically it has been established that in Finland local government system is much decentralized, i.e. there are a great many municipalities (452). In its turn, this determined the formation of a favourable environment and the emergence of the need to rise for a separate institution, the Association of Local and Regional Authorities which could coordinate common projects of the municipalities and to prompt them to focus their activity more on the implementation and satisfaction of citizens' needs. It is worth mentioning once again that the Association of Local and Regional Authorities was the first one in Finland to speak about the spread of quality management models in the public sector. As the data from the qualitative research has showed, this institution was the principle catalyst disseminating 
among Finnish public administration institutions the pilot project of ISO standards which was as part of the programme "Quality and the Community Programme" initiated by the Association of Local and Regional Authorities.

According to the expert of this institution, S. Sundquist, at that time, i.e. in 1992 - 1993, in Finland, neither ministries nor other agencies of the central government demonstrated the thinking that would uphold the point that institutions should ground their activity on quality management models in order that they would not only more quickly get out of a deep economic depression, but would function together more effectively and would more satisfy citizens' expectations. "While the then financial depression was really not ridiculous", continuing the idea in a notably serious vein $S$. Sunquist adds that municipalities are those last institutions that directly provide services to citizens; therefore, the objective of the institution of local and regional authority is to prompt municipalities to focus their activity on the fulfilment of citizens' needs, and it is that institution which has to offer "something" with respect to quality assurance. ${ }^{41}$

From the assertions of the above-mentioned respondent one can get the impression that the Association of Local and Regional Authorities, being still in a "grey" administrative field of the spread of quality initiatives, was the first one which, because of the emerged favourable conditions, "took roots". Although the representatives of this institution, S. Sunquist and Marianne Pekola-Sjoblom, claim that they started to popularize quality initiatives only in the name of citizens, as the theory of institutionalism postulates, each institution has its own personal interests that are not incompatible with the spread of institution's competence and powers which ensure for institutions not just the survival, but also the so much desired prosperity. An active participation during the initiation and supervision of the way participants of the pilot project were implementing the ISO standards enabled the Association of Local and Regional Authorities in 1995 to issue the document "Total Quality Management in Municipal Service Provision" which, according to S. Sundquist, was the first national document (as stated by $S$. Sundquist, in a particular way equalling to a quality strategy) which systematised and defined the quality management and its peculiarities in Finland. Meanwhile the prerogative of the issue of such documents, though of a recommendatory nature, would usually lie in the hands of central institutions such as, for instance, the Ministry of Finance. This illustrates in what way the Association of Local and Regional Authorities, existing just as an adviser for municipal affairs, by the issue of the document that was the most important one in the context of quality management, ensured the institution's influence in the administrative field of quality initiatives with respect to

\footnotetext{
${ }^{41}$ Salme Sundquist, supra note 17.
} 
prospective and up-coming field players. This fact, in its turn, helped to entrench a natural self-seeking interest of every institution to expand the institution's competence and boundaries of its operation.

The situation that the influence of the Association of Local and Regional Authorities has remained notably significant in the Finnish administrative field of quality initiatives is also testified to by the fact that in 1998 this institution, together with the Ministry of Finance, issued a document adjusted for the whole public sector "Quality Strategy for Public Services", which has become a substantial document consolidating the Finnish quality policy in the country. The interest in the issue of this strategy denotes that the Ministry of Finance, including under its organization the Department of Public Management, has also determined to "find its way" into the administrative field of the spread of quality initiatives where in accordance with a favorable institutional nature (it is the ministry), it seems it and had to dominate. In other words, it is as if there were a wish to retrieve an unused "zone of influence" which could help to strengthen the image in the eyes of citizens and would add to additional legitimacy.

However, except for the creation of the mentioned quality strategy, the Ministry of Finance has not done any more substantial work during the last decade in the context of the administrative field of quality initiatives. Nevertheless, important preparatory work for the CAF that was carried out during the Finland's Presidency in 1999 notably incorporated members of the Ministry of Finance not only into the formation of this initiative, but also the support of it in general. This, as reported by $\mathrm{K}$. Holkeri, determined the concentration of the Ministry of Finance exclusively upon this quality initiative in its dissemination on the plane of the Finnish public sector. According to this expert, the support for the CAF dissemination by the Ministry of Finance was also determined by the exceptional character of this quality initiative: "We are not agitating precisely for the CAF model and we suggest for public institutions to choose at their discretion the most acceptable to them quality instrument; but we have to be honest, as the CAF is exclusively intended for public organizations, therefore, there are no companies that will support it and, consequently, we have to carry out this work". ${ }^{42}$ In other words, it is possible to presume that having concentrated on an entirely new spread of quality initiative that is intended for public organizations alone, which makes the CAF exceptional and attractive, the Ministry of Finance has employed the CAF as a means that would help to consolidate its powers and positions in the administrative field of the spread of quality initiatives.

${ }^{42}$ Katju Holkeri, supra note 16. 
The Ministry of Finance has been disseminating the CAF among organizations of the public sector in national quality conferences held every two years since 2000. In addition, the Ministry of Finance has been organizing CAF pilot projects which include a limited and small number of participants: 4-5 institutions are introduced to the concept of the CAF. In such seminars where close relationships are maintained with each institution, the Ministry of Finance helps the organizations to become interested in the CAF and at the same time to expand the number of CAF users in the country, which, in its turn, increases the influence of the Ministry of Finance with regard to other actors of the administrative field, since in Finland the CAF is practically being propagated by this institution alone. The fact that pilot seminars of such a character are effective is also proven by the case of the Vaasa Municipality when its Administration Director Veli-Matti Laitinen after participation in such an event remained very fascinated with the CAF model: "Most likely in 2009 we will start implementing the CAF, because during the participation in a special group organized by the Ministry of Finance I understood that it is an especially attractive and appropriate for the public sector quality initiative which, after all, is not difficult to apply". ${ }^{43}$ Thus, although during the qualitative research the representatives of the Ministry of Finance constantly did not forget to add that they urged public institutions not to apply the CAF, but advised them to employ at least some quality management initiative in their activity, nevertheless it is evident that the spread of the CAF helps the Ministry of Finance to realize self-seeking institutional interests highlighted in the theory of institutionalism, i.e. those of the concentration of one's powers and influence in the administrative field.

The fact that the typically unnamed interest of field actors relates to the reinforcement of one's powers and influence in respect of other institutions is also proved by the evolution of the Finnish Institute of Public Management (HAUS). As findings of the qualitative research have revealed, from 1995 to 2002 the HAUS was a state establishment under the Ministry of Finance and in 2002 was converted into a state owned limited company, which, according to the HAUS Director for Training L. Luoto, ensured a great independence of the HAUS: "Formerly we were an agency under a very large wing of the Ministry of Finance; and as the government does not subsidize us anymore, so currently we have invaded expanses of the market ourselves". ${ }^{44}$ In other words, after 2002 the institutional powers of the HAUS were extended, since the influence exerted on them by the Ministry of Finance, as it turned out in the course of the qualitative research, has remained very symbolic: "Presently we meet with representatives of the ministry

\footnotetext{
${ }^{43}$ Veli-Matti Laitinen, personal interview, April 3, 2008.

${ }^{44}$ Lauri Luoto, personal interview, April 8, 2008.
} 
only once a year in representative meetings where they just ask about the proceeding of our activity, but they can neither tell nor order us anything, though it is clear they wait from us good results". ${ }^{45}$ Reasons for such annual meetings are that the HAUS activity is based on the provision of training for civil servants. Although, the HAUS, as well as other training institutions of the administrative field of quality initiatives is participating in the field under conditions of the market, it nonetheless has better start positions and a greater input, because even earlier, from 1971 to 1995 , it was an agency providing training for civil servants under the central government. Thus, it can be presumed that with well-developed networks of relations the HAUS is gaining an advantage in the training market. It might be that the agency's restructuring was aimed at by the institution in a consistent way as a self-seeking interest to achieve such a status that would enable it to exist not just nearly independently, but to possess good positions in the competitive context of the administrative field.

Although expert of the Finnish Ministry of Finance, K. Holkeri, claims that there is no systematic data on how many CAF users there are in the country, she insists that their number is increasingly growing: "Every day we send a lot of copies, the number of people applying by phone is increasing ... ". ${ }^{46}$ However, this development, at least theoretically, would have to be checked with the help of awards organized by "Excellence Finland", where, in order to win the quality prize, participating organizations are strongly recommended to ground their activity on the EFQM model of quality management which most frequently turns out to be an important criterion ${ }^{47}$ in the assessment of organizations. ${ }^{48}$ Therefore, it can be observed that in the Finnish administrative field the monopoly of the spread of particular quality management initiatives is being reduced even more. Moreover, it becomes distinct that different field actors are supporting the dissemination of different quality initiatives: the Association of Local and Regional Authorities standards of the ISO 9000 series, the Ministry of Finance - the CAF and "Excellence Finland" - the EFQM model. Differing positions of field institutions demonstrate that each actor is trying to achieve not only public, but also different interests characteristic of its institution alone. Probably, this can also account for the development related to institutional competencies.

However, when it is convenient for institutions of the administrative field they turn inter-institutional deals and communication relations to their own advantage.

\footnotetext{
${ }^{45}$ Ibid.

${ }^{46}$ Katju Holkeri, supra note 16.

${ }^{47}$ As it has been already mentioned, although the CAF and EFQM models for the greater part are similar (after all the CAF was created on the basis of the EFQM model), however, in order to win a national quality reward in Finland, public organizations should have implemented the EFQM quality model.

${ }^{48}$ Timo Tulonen, personal interview, April 9, 2008.
} 
To illustrate, the Ministry of Finance and the Association of Local and Regional Authorities have been successfully collaborating, jointly issuing important national documents related to the spread of quality in the public sector. Thus, forming the policy of quality management institutions also aims at personal interests to consolidate their influence with regard to actors of the administrative field.

Hence, although in the previous section it has been observed that the Finnish administrative field of the spread of quality initiatives is "transparent" and favourable for a constructive dialogue, due to the effect of individual institutional interests to expand one's competence and powers, actors of the field get involved into at first glance a hardly discernible contest. In its turn, the formation of quality initiatives in Finland is related to the public interest. For instance, the Ministry of Finance simply suggests and encourages public organizations to employ quality initiatives. The impression can be made that institutional interests are pilot try-outs that later would stimulate more extensive changes of a broader scope. Thus, the Ministry of Finance does not seek to influence quality changes in a centralized way, but rather to achieve this through the indirect coordination of the process of quality spread and stimulation of changes.

\section{INTERESTS OF ACTORS IN THE LITHUANIAN ADMINISTRATIVE FIELD OF THE APPLICATION OF QUALITY INITIATIVES}

On the basis of the $2005-2006$ and 2007 - 2010 plans of the means for the implementation of the strategy of public administration development till 2010, it can be observed that as the principle executive responsible for the improvement of the quality of services provided by the public sector organisations is the Ministry of the Interior. In the course of the qualitative research, although persistent attempts were made to contact representatives of the Public Administration Development Division of the Public Administration Department of this institution who were responsible for the implementation of quality policy, the efforts were unsuccessful. This shows the reticence of this institution's activity which was also confirmed by several other respondents. In this work we have already established that in the context of the spread of quality initiative the Ministry of the Interior is, first of all, simulating the reforms, as they are being transferred by the means of spontaneous "copying" without going into the country's needs of quality initiatives.

An imitative character of quality reforms is also confirmed by the inactivity of the Sunset Commission, one of the main functions of which is to consult and put forward proposals to the Government of the Republic of Lithuania on the improvement of the quality of services provided by public institutions. However, the 
fact that this commission is practically incompetent is confirmed not only by the representatives of opposition parties A. Kubilius ${ }^{49}$ and G. Steponavičius ${ }^{50}$, but also by results of the research carried out by the New Public Management Foundation where it is stated that the Sunset Commission does not undertake to implement new quality methods. ${ }^{51}$ Thus, if the commission specially created for the given purpose practicably does not advise on anything, all the more then it would be difficult to expect other than imitative reforms from the layers of the ministry.

However, more carefully analysing the contexts of the spread of initiatives it is possible to make assumptions about the interests that have led the ministries to initiate the spread of quality initiatives. Comparing self-seeking interests raised by institutionalism with institutional interests of the Ministry of the Interior one cannot reject that possibility, due to the implementation of the CAF emerged opportunities for Lithuanian civil servants to travel to cognitive-consultative European conferences and enhance their own institutional interest. But one should not look at this interest only through the prism of negative judgment. After all, wishes of civil servants can also be linked with the baggage of practical knowledge acquired during conferences and which could be realized in the Lithuanian civil service.

Another participant in the Lithuanian administrative field of the spread of quality initiatives, the Lithuanian Institute of Public Administration, has consistently strengthened its influence on the field's plane. Having "established" relations with representatives of the Ministry of the Interior in the already mentioned international conference, soon, these two institutions issued the 2005 and 2006 Lithuanian versions of the CAF. When preparing this project and choosing partners for the issue of the CAF the competition was organized, but, as the Chief Consultant of the Lithuanian Institute of Public Administration A. Arbatauskas puts it, the Lithuanian Institute of Public Administration was the one and only suitable candidate: "The Ministry of the Interior proposed that we become their partners, because they did not have anyone else to speak to". ${ }^{52}$ Although a minimal competitive condition was at least to have the experience of the participation in CAF international conferences, actually, it could be fulfilled only by the Lithuanian Institute of Public Administration. Certainly this institution is probably the most competent organization concerning the consulting on CAF questions in Lithuania; however, maybe it would be possible to make the assumption that on the plane of the spread

\footnotetext{
49 Andrius Kubilius, supra note 37.

50 Gintaras Steponavičius, personal interview, April 23, 2008.

51 Chorst Claus, Gytis Janišius, and Kęstutis Masiulis, Saulèlydžio komisijos veiklos 2007 m. ekspertizè: Naujosios viešosios vadybos fondo tyrimas (The Expertise of the Sunset Commission's Activity of 2007: Research by the New Public Management Foundation) (Vilnius, 2008) // http://www.nvv.lt/../images/stories/saulelydis_ekspertize.pdf.

52 Artūras Arbatauskas, supra note 23.
} 
of quality during inter-institutional deals partners are in reality creamed off already in an informal environment.

Turning to the training in quality initiatives, according to A. Arbatauskas, the Lithuanian Institute of Public Administration also organizes free cognitive lectures of several hours about the CAF model for public sector institutions. ${ }^{53}$ On the basis of a theoretical institutionalism perspective, it can be presumed that the institutional interest would not just engage organizations in a new quality management model that would help to improve the organization's activity, but at the same time would expand functions of the Lithuanian Institute of Public Administration itself monopolizing the training in the administrative field.

As far as the CAF model is concerned, the Lithuanian Institute of Public Administration probably does not have any serious rivals in the context of the administrative field. A. Arbatauskas himself considers that the knowledge related to the CAF in Lithuania could be shared by more organizations that have already implemented this model or those that are still in the process of the implementation (as, for example, Kaunas City Municipality) rather than by training agencies which are specially organizing various types of training for public sector servants. ${ }^{54}$

However, although in the Lithuanian field of the spread of quality initiatives there is, in fact, one more substantial actor in the context of training, i. e. Uolektis, Ltd., nevertheless, it is a rival to the Lithuanian Institute of Public Administration only as much as it relates to the development of all quality management systems in general, as this private company provides consultations and training for public organizations according to the guidelines of the ISO standards.

However, in the context of quality management training, Uolektis, Ltd. has a great input, as already since 1994 it has been providing consultative services related to the implementation of standards of ISO series. The company's competence ${ }^{55}$ in the provision of training concerning the implementation of ISO standards is not doubted by the Director of this company Alma Žemaitienè:

Public organizations are approaching us themselves and, especially, large ones, because they find it difficult to manage their processes. The endeavour of medical establishments to find us has been particularly noticeable, as because of mistakes made by medical specialists one may suffer great losses, since nowadays customers are claiming millions for the compensation of harm and the times when 1000-2000 litas [Lithuanian currency] were claimed are long-gone.

\footnotetext{
53 Ibid.

54 Ibid.

55 Besides, the competence of "Uolektis, Ltd." in quality management questions is validated by the fact that its representatives already in 1996 took participation in the preparation of the Lithuanian national quality programme. In addition, the Director of "Uolektis, Ltd." Dr. Alma Žemaitienè is an expert of the Lithuanian National Quality Prize Competition. Also, organization's clients put trust in "Uolektis, Ltd.", because their long - time partners include the German company "TUV Uolek".
} 
Therefore, ISO standards are an excellent means for them in order to reduce the number of discrepancies. In addition, they help to avoid the paying of compensations to costumers ensuring within organizations a well-tuned functioning of processes, while the saved finances when the given situation arises will be shifted to the development of medical infrastructure. ${ }^{56}$

The fact that especially public health service institutions themselves are approaching Uolektis, Ltd. with respect to quality management training is also confirmed by the Manager-Consultant of this company Evelina Petrauskaite:

They get interested in standards of ISO series one after another, it is as if catching. Probably they rush to us, because they are indignant at the quality of provided services of many firms that have sprung recently and which are carrying out their services superficially. After all, clients are choosing us, because, ultimately, the factor of experience prevails over - on the website there is the data published about who and how many times we have consulted and whether training is being provided. ${ }^{57}$

This position of representatives of Uolektis, Ltd. reflects not only the confidence in their organization as far as the provision of services in the context of quality management is concerned, but also creates the impression of the protection of the quality initiative of ISO standards that purportedly is also more acceptable, as well as for public sector organizations which on their own initiative are approaching Uolektis, Ltd on the question of training. Also, in the respondents' rhetoric one can notice that in the context of the training in ISO standards there exists a competitive environment where a decisive role is played by the reputation and experience of the training organization. However, all the more as it is a private company operating under conditions of the market, it is not difficult to identify the organizational interests of Uolektis, Ltd. which include striving to occupy as much as possible of the niche of the administrative field of quality initiatives in the context of training.

In the context of the administrative field of quality initiatives, the influence of Uolektis, Ltd. is also being strengthened by the situation that this company, established in Kaunas, has expanded its activity on a national scale:

Since we are an initiator of the spread of quality initiatives in the country providing services of such a nature, having accumulated sufficient experience, we are working throughout Lithuania. Moreover, the market of quality initiatives is not characterized by just a regional nature. For example, for already not one year we have been actively consulting on questions of quality management the State Medical Audit Inspectorate under the Ministry of Health established in

${ }^{56}$ Alma Žemaitienè, personal interview, May 9, 2008.

${ }^{57}$ Evelina Petrauskaitè, personal interview, May 9, 2008. 
Vilnius, also Vilnius City University Hospital and Vilnius University Emergency Hospital. ${ }^{58}$

Such an "invasion" into Vilnius by the company from the former provisional capital narrows monopolist claims of the Lithuanian Institute of Public Administration that existed in Vilnius for a long period of time in an overall context of the training of the spread of quality systems. In its turn, in the context of quality management training such destruction of monopolist ties ensures for public administration institutions more accessible all-around information on the selection and application of different quality initiatives.

Meanwhile the research carried out in the context of the spread of quality initiatives also receives considerable attention from field actors, as agencies create a specific competitive environment. At this point, even A. Arbatauskas acknowledges that in the sense of research the Lithuanian Institute of Public Administration is facing competition from the Public Policy and Management Institute, the Quality Management Association and other agencies.

The fact that in the context of quality initiatives the Lithuanian Institute of Public Administration does not have the monopoly of the research being carried out is also proven by the circumstance that the order of 2006 by the Ministry of the Interior to carry out the research on the monitoring of the implementation of quality management methods in the public administration institution was won in a public competition by the Public Policy and Management Institute. However, as revealed by an analyst of this institution, Ramune Černiūtè, the Ministry of the Interior has been allocating an insufficient amount of finances for these studies; therefore, privately functioning agencies seeking to qualitatively carry out the research have to even "tighten" at their own charge. ${ }^{59}$ In other words, because of the ministry's insufficient attention to research, questions on their financing may "drive off" actors that are best prepared for the participation in competitions. As noticed by R. Černiūtè, in Lithuania there are not many companies analyzing quality in the public sector. Nevertheless, at the same time this respondent recalled that between periods of the implementation of the project from the EU structural funds' support in 2004 - 2006 and 2007 - 2013 consultative agencies working in the niche of the regional policy "switched" to the field of the research on quality initiatives: "With the doldrums in the context of SF, agencies moved to competitions in quality projects according to the logic that it is necessary to participate in all orders existing in the market" ${ }^{60}$

\footnotetext{
${ }^{58}$ Ibid.

59 Ramunè Černiūtè. personal interview, April 25, 2008.

${ }^{60}$ Ibid.
} 
The inter-institutional competitive practice extending in the administrative field of the research on the spread of quality management and a large number of "capable" field players is also proven by the fact that the research by the order of the Ministry of the Interior on possibilities of the application of quality management methods in Lithuanian public administration institutions carried out by the Centre for Total Quality Management of Kaunas University of Technology in 2005 was left in practice unused, because, according to Povilas Vanagas: "Practically, this study has remained in a drawer - a very minimal amount of information was used out of it, since in Lithuania the version of quality management offered by the Department of Quality Management of Vilnius University is being followed". ${ }^{61}$ Meanwhile, in the area of quality management, universities embracing vast networks of the human resources potential become competitors with other field players in the administrative field of quality management not only in the context of research, but also consultations. For instance, in 2003 - 2004 when preparing a new National Quality Programme the influence of the Department of Quality Management of Vilnius University was felt, as the Scientific Supervisor of preparatory work was the then Scientific Supervisor of the Department of Quality Management Juozas Ruževičius. ${ }^{62}$ The possibilities of quality management specialists of Kaunas University of Technology to operate in the administrative field on a broader scale have been also expanded by the participation in the activity of the Lithuanian Quality Management Association (LQMA) ${ }^{63}$ one of the founders of which is Kaunas University of Technology and the President of the LQMA itself is a Professor of Kaunas University of Technology, Povilas Vanagas. This shows that the interest of institutions is invested while searching for new niches to expand their competence in the context of the administrative field, whereas the spread of competence, in its turn, also manifests itself through the creation of new structures.

Thus, in the context of the Lithuanian administrative field of the spread of quality initiatives a fair number of actors are competing for research and training in quality; however, scarce allocations by the ministry to perform the research may contribute to the situation when "the strongest players" may not participate in competitions or there is the possibility that the research will be carried out carelessly, which demonstrates insufficient interest on the part of the Government of the Republic of Lithuania to carry out the research on quality management in the public sector in an optimal way. Meanwhile interests of field actors are related to

61 Povilas Vanagas, personal interview, May 7, 2008.

62 During the qualitative research Povilas Vanagas acknowledged that the Department of Quality of Vilnius University is a very "strong" field player and Juozas Ruževičius - an especially competent quality management specialist (ibid.).

63 The Lithuanian Quality Management Association was established in 2001 and one of its fundamental goals is to help institutions of country's management and public administration to improve the quality of their activity in the best way that would ensure the satisfaction of citizens' needs at the lowest costs. 
the consolidation of influence and powers in the context of the administrative field of quality initiatives.

\section{CONCLUSIONS}

1. Having analyzed the application of quality management systems in the practice of the Finnish and Lithuanian public sectors it has been observed that in both countries their initiation was determined by certain unforeseen and accidental circumstances. However, when initiating the models of quality management, in Finland, during the implementation of the ISO standards in an organized way the experimental (pilot) project was employed; whereas, in Lithuania, the CAF was adopted in the so-called manner of copying. Also, both in Finland and Lithuania, visions for quality systems of some representatives of the administrative apparatus contributed to a more rapid rise in the national public administration systems of the countries. On the one hand, the carried qualitative research has revealed that, in Lithuania, among senior bureaucrats one obvious leader appeared who was an active supporter of the CAF simply by itself. On the other hand, in Finland, the bureaucratic apparatus was impelled to get involved into not only the creation of a new EU quality initiative, but also the support of it by an objective circumstance, Finland's Presidency of the whole EU during a decisive period of quality initiatives when fundamental work for the CAF model was being carried out.

2. Analysing the contribution of the political elite to innovative ideas in the public sector, it can be noted that Finland displays not just a unanimous attitude towards changes, but its rotating governments also ensure the succession of innovative visions. Meanwhile Lithuanian governing parties do not have clear visions for innovative initiatives of the public sector and opposition parties generating NPM ideas have not gained access to the central government for already eight years in a row. In addition, the influence of Lithuania's foreign experts on the ideas of the public sector modernization has been only fragmentarily manifested, while in Finland great attention is paid by the highest government layer to how to prepare in the most efficient possible way and develop innovative instruments of the public sector. This means that not only the most famous globally external experts are invited to carry out studies of possibilities, but that their suggestions are most frequently usefully realized in the practice of the Finnish public sector.

3. Although the Finnish administrative field of the spread of quality initiatives is favourable for a constructive dialogue, due to the effect of individual institutional interests to expand one's competence and powers, actors of the field get involved into what is at first glance hardly a discernible contest. Yet, the formation of quality 
initiatives in Finland is related to the public interest, because public organizations are simply encouraged to employ any of quality initiatives they choose. Thus, institutional interests are pilot try-outs that later would stimulate more extensive changes of a broader scope. Therefore, the Ministry of Finance does not seek to influence quality changes in a centralized way, but rather to achieve this through the indirect coordination of the process of quality spread and stimulation of changes.

4. In the context of the Lithuanian administrative field of the spread of quality initiatives a fair number of actors are competing for research and training in quality. Therefore, interests of field actors are related to the development of competence and the consolidation and reinforcement of influence and powers in the context of the administrative field of quality initiatives. For example, the interest of institutions while searching for new niches to expand their competence in the context of the administrative field also manifests itself through the creation of new structures. Besides, comparing self-seeking interests raised by institutionalism with interests of Lithuanian public administration actors one cannot reject the possibility that, due to the implementation of quality initiatives, opportunities emerged for Lithuanian civil servants to travel to cognitive-consultative European conferences and enhance their own institutional interest.

\section{BIBLIOGRAPHY}

1. Chorst, Claus, Gytis Janišius, and Kęstutis Masiulis. Saulèlydžio komisijos veiklos $2007 \mathrm{~m}$. ekspertizè: Naujosios viešosios vadybos fondo tyrimas (The Expertise of the Sunset Commission's Activity of 2007: Research by the New Public Management Foundation). Vilnius, 2008 // http://www.nvv.lt/../images/stories/saulelydis_ekspertize.pdf.

2. DiMaggio, Paul J., and Walter W. Powell. "The iron cage revisited institutional isomorphism and collective rationality in organizational fields." In: Walter W. Powell and Paul J. DiMaggio, eds. The New Institutionalism in Organizational Analysis. Chicago: University of Chicago Press, 1991.

3. Kubilius, Andrius, et al. Dešinioji alternatyva: Sèkmès Lietuva. Konservatyvioji politine programa (The Right Alternative: Success Lithuania. Conservative political programme). Vilnius, 2003.

4. Kundrotienè, Nijolè, and Kęstutis Rekerta. "Strateginio planavimo diegimas Lietuvos viešojo administravimo institucijose" (Implementation of Strategic Planning System in Lithuanian Public administration). Viešoji politika ir administravimas No. 3 (2002): 57-63. 
5. Lane, Jan-Erik, and Svante Ersson. The New Institutional Politics. Performance and Outcomes. London, New York: Routledge, 2000.

6. Lane, Jan-Erik. Viešasis sektorius: sąvokos, modeliai ir požiūriai (The Public Sector: Concepts, Models and Approches). Vilnius: Margi raštai, 2001.

7. March, James G., and Johan P. Olsen. Rediscovering Institutions. The Organizational Basis of Politics. New York: Free press, 1989.

8. March, James G., and Johan P. Olsen. Institutional Perspectives on Governance. Bergen: Norwegian research centre in organization and management, 1993.

9. March, James G., and Johan P. Olsen. Democratic Governance. New York: The Free Press, 1995.

10. Peters, B. Guy. Biurokratijos politika (The Politics of Bureaucracy). Vilnius: Pradai, 2002.

11. Pollitt, Christopher. Trajectories and Options as International Perspective on the Implementation of Finnish Public Management Reforms. Helsinki: Ministry of Finance, Public management department, 1997.

12. Pollitt, Christopher, and Geert Bouckaert. Viešojo valdymo reforma: lyginamoji analize (Public Management Reform: A Compararative Analysis). Vilnius: Algarvè, 2003.

13. Salminen, Ari. "The Reform "Industry" in Finnish Government." In: B. Guy Peters and John Pierre, eds. Politicians, Bureaucrats and Administrative Reform. London, New York: Routledge, 2001.

14. Scott, Richard W. Institutions and Organizations. London, New Delhi: Sage publication, 1995.

15. Sundquist, Salme. "Finnish Local authorities experiences with use of ISO 9000." In: Elker Loffler and Mirko Vintar, eds. Improving the Quality of East and West European Public Services. Hampshire: Ashgate, 2004.

16. Temmes, Markku. "Finland and New Public Management," International Review of Administrative Sciences Vol. 64 (1998): 441-456.

17. Turunen, Juhari, Jorma Kajalainen, and Teuvo Metsapelto. Finnish Public Management: Building Sustainable Quality. Finland: Ministry of Finance, Edita Prima Ltd, 2006. 